\title{
Effect of Yeast and Lactic Acid Bacteria Probiotic on The Growth of Tiger Shrimp (Penaeus monodon), Microbiology and Water Quality
}

\author{
Nurliana Nurliana $^{1 *}$, Fauzia Khairunisa $^{2}$, Baharuddin H. Siregar ${ }^{2}$, Dicky H.M. Harahap ${ }^{3}$, Rumi S. Zamzami ${ }^{4}$, Siti R. \\ Ayuti $^{5}$, Ismail Ismail ${ }^{1}$, and Rastina Rastina $^{1}$ \\ ${ }^{1}$ Laboratory of Veterinary Public Health, Faculty of Veterinary Medicine, Universitas Syiah Kuala, 23111 Banda Aceh, Indonesia \\ ${ }^{2}$ Faculty of Veterinary Medicine, Universitas Syiah Kuala, 23111 Banda Aceh, Indonesia \\ ${ }^{3}$ Faculty of Marine and Fisheries, Universitas Syiah Kuala, 23111 Banda Aceh, Indonesia \\ ${ }^{4}$ Laboratory of Clinic Faculty of Veterinary Medicine Universitas Syiah Kuala, 23111 Banda Aceh, Indonesia \\ ${ }^{5}$ Laboratory of Biochemistry, Faculty of Veterinary Medicine, Universitas Syiah Kuala, 23111 Banda Aceh, Indonesia
}

\begin{abstract}
Yeast and lactic acid bacteria are often used as probiotics. This study aimed to determine the effect of giving yeast and LAB probiotic using fruit waste as a microbial medium on the productivity of tiger shrimp postlarvae (Panaeus monodon). As many as 120 tiger shrimp post-larvae were acclimatized for 2 days. The tiger shrimps post-larvae were divided into 4 treatments; a control group tiger shrimp post larvae without given yeast and LAB probiotic $(\mathrm{P} 0)$; treatment $1(\mathrm{P} 1)$; treatment $2(\mathrm{P} 2)$ and treatment $3(\mathrm{P} 3)$ in sequence shrimp post larvae given $25 \mathrm{ml} ; 50 \mathrm{ml}$; and $75 \mathrm{ml}$ yeast and $\mathrm{LAB}$ probiotic/15 L of water. Yeast and LAB probiotic was given in shrimps post-larvae live media for 3 weeks(once per week). Data were analyzed using analysis of variance (ANOVA) following the Duncan test. The results of this study showed that yeast and $\mathrm{LAB}$ probiotic at a dose $25 \mathrm{ml} / 15 \mathrm{~L}$ of water can increase the growth of tiger shrimp post-larvae, reduce the amount of Vibrio sp. and maintain the quality of tiger shrimp post larvae environment.
\end{abstract}

Keywords: fruit waste, tiger shrimp, growth, water quality.

\section{Introduction}

Tiger shrimp (Penaeus monodon) is a mainstay fishery commodity in Indonesia and can increase the country's foreign exchange from non-oil exports. This type of shrimp is a native shrimp of Indonesia which has been cultivated since a few decades ago [1]. In the last few years, many pond farmers have suffered losses due to decreased production of their tiger shrimp farming business. This happens a lot in the stages after tiger shrimp larvae due to a decrease in the immune system of tiger prawns which results in mass death [2].

Control of tiger shrimp disease can be done through improving the living environment. Improving the quality of the environment of shrimp has been done in various ways, including the use of antibiotics and chemicals. But this method raises a bigger problem. The use of antibiotics as a Growth Promoter in a shrimp environment that is not according to the rules causes resistance to pathogenic microbes and antibiotic residues in the product. Currently, fishery exports must meet food safety requirements including antibiotics and its derivatives, free of heavy metals, sanitary ware and hygiene $[2,3,4]$.

One alternative solution to reduce the use of antibiotics is by giving probiotics. Probiotics are live microbial agents that have beneficial effects on the host by modifying the microbial community or associating with the host, ensuring improvements in feed use, improving nutrition and the host's response to disease and improving the quality of the environmental threshold $[5,6,7]$. Commercial probiotics on the market are sold at quite high prices and do not provide maximum results. This study uses growth media derived from fruit waste whose products are expected to be reachable by the farming community. Therefore the following article explains the effects of providing probiotics made from fruit waste as a medium for making probiotics so that it is more economical to increase tiger shrimp productivity and reduce costs to be more efficient.

\section{Materials and Methods}

\subsection{Research Procedure}

\subsubsection{Maintenance of tiger shrimp and yeast and lactic acid bacteria treatment}

This study used 120 PL30 tiger shrimp which were kept for 23 days. Before treatment, shrimp were kept for 2 days with the same conditions, after that the shrimp were divided into 4 random treatments and then given probiotics Yeast and lactic acid bacteria different for 21 days then consisting of control (P0) maintained without 
administration yeast and lactic acid bacteria probiotics from fruit waste filtrated; treatment 1 (P1) maintained by administering yeast and lactic acid bacteria probiotics from fruit waste filtrate at a dose of $25 \mathrm{ml}$; treatment 2 (P2) was maintained by administering yeast and lactic acid bacteria probiotics from fruit waste filtrate at a dose of $50 \mathrm{ml}$ and treatment $3(\mathrm{P} 3)$ maintained by administering yeast and lactic acid bacteria probiotics from fruit waste filtrate at a dose of $75 \mathrm{ml}$. Rearing tiger shrimp using seawater with a volume of 15 liters per treatment. Provision of yeast and lactic acid bacteria probiotics is carried out every week ( 7 days) on the $2^{\text {nd }}$, $9^{\text {th }}$ and $16^{\text {th }}$ days, observing on the $23^{\text {rd }}$ day.

\subsubsection{Calculation of the number of fungi and lactic} acid bacteria in the yeast and lactic acid bacteria probiotic solution and the number of Vibrio sp and lactic acid bacteria in tiger rearing water.

Calculation of the number of fungi and lactic acid bacteria on Vibrio sp. using the Total Plate Count (TPC) method. The TPC method uses $10 \begin{array}{lllll}10 & 1 & -10 & 6 & \text { decimal }\end{array}$ dilutions. Calculation of the number of fungi and lactic acid bacteria in yeast and lactic acid bacteria probiotics is done by taking $1 \mathrm{ml}$ of suspension on day 0 , day 1 , day 2 , day 3 and day 4 . The results of each dilution were grown on Potato Dextrose Agar (PDA) media, incubated at 20$25^{\circ} \mathrm{C}$ for 7 days. Lactic acid bacteria were grown on MRS agar media, incubated at $37^{\circ} \mathrm{C}$ for 24 hours.

Calculation of the amount of Vibrio sp and lactic acid bacteria is done by taking $1 \mathrm{ml}$ of maintenance water and then diluted decimal, then grown on TCBS and MRS media and incubated at $37^{\circ} \mathrm{C}$ for 24 hours.

\subsubsection{Observation of tiger shrimp growth}

Observation of tiger shrimp growth was carried out at each treatment by measuring shrimp weight (g) using digital scales and shrimp body length $(\mathrm{mm})$ using calipers which were carried out before treatment and after 7 days from the $16^{\text {th }}$ day of treatment giving R \& BAL probiotics.

\subsubsection{Measurement of water quality for tiger shrimp maintenance}

Water quality measurement is carried out using a refractometer to measure salinity, DO meter to measure dissolved oxygen levels and a $\mathrm{pH}$ meter to measure $\mathrm{pH}$ and water temperature.

\subsection{Data Analysis}

Data obtained from observations were analyzed using analysis of variance, T-test and Duncan test.

\section{Results and Discussion}

\subsection{Number of fungi and lactic acid bacteria on yeast and lactic acid bacteria}

Probiotics yeast and lactic acid bacteria contain microorganisms in the form of Lactobacillus sp. and boletus. The calculation of the number of BAL and fungus is carried out every day during the incubation period. The mean \pm SD number of LAB and fungus in $\mathrm{R} \& \mathrm{BAL}$ fluid based on the incubation period $(\log 10 \mathrm{CFU} / \mathrm{ml})$ is shown in Table 1.

Table 1. Average \pm SD of lactic acid bacteria and fungi in yeast and lactic acid bacteria fluid based on incubation time (log 10 $\mathrm{CFU} / \mathrm{ml}$ )

\begin{tabular}{ccc}
\hline \multirow{2}{*}{$\begin{array}{c}\text { Time } \\
\text { Incubation }\end{array}$} & \multicolumn{2}{c}{ Number of Colonies } \\
\cline { 2 - 3 } & $\begin{array}{c}\text { Lactic acid } \\
\text { bacteria }\end{array}$ & Yeast \\
\hline H0 & $5.766 \pm 0.253^{\mathrm{a}}$ & $3.083 \pm 1.282^{\mathrm{a}}$ \\
H1 & $6.148 \pm 0.079^{\mathrm{a}}$ & $5.427 \pm 0.683^{\mathrm{b}}$ \\
H2 & $6.396 \pm 0.064^{\mathrm{a}}$ & $5.955 \pm 0.497^{\mathrm{b}}$ \\
H3 & $6.176 \pm 0.724^{\mathrm{a}}$ & $4.371 \pm 1.833^{\mathrm{ab}}$ \\
H4 & $6.191 \pm 0.923^{\mathrm{a}}$ & $3.789 \pm 1.176^{\mathrm{ab}}$ \\
\hline
\end{tabular}

Based on statistical analysis, the incubation time had no significant effect $(\mathrm{P}>0.05)$ on the number of yeast and lactic acid bacteria probiotics, but it had a significant effect $(\mathrm{P}<0.05)$ on the number of yeast on yeast and lactic acid bacteria. The average number of lactic acid bacteria colonies and fungi at most based on incubation time was on the second day with an average number of LAB colonies of $6.396 \log 10 \mathrm{CFU} / \mathrm{ml}$ and the number of fungal colonies of $5.955 \log 10 \mathrm{CFU} / \mathrm{ml}$. Fungi with water content correlated strongly because of the higher the water content, the more the number of fungi. The increased number of fungi is due to the composition of feed derived from grains that contain water, carbohydrates, proteins, minerals, fats, and vitamins which are nutrients that support the growth of fungi.

\subsection{Growth of Tiger Shrimp}

Tiger shrimp productivity can be seen from the growth of shrimp based on weight and length, which is measured at the beginning of the maintenance period and the end of the maintenance period of tiger shrimp. Average \pm DS weights and length of tiger shrimp based on treatment at the beginning and end of the maintenance period are shown in Table 2 and Table 3.

Based on statistical analysis, the provision of probiotics yeast and lactic acid bacteria in groups $\mathrm{P} 0$ and $\mathrm{P} 1$ had a significant effect $(\mathrm{P}<0.05)$ on the weight gain of tiger shrimp. The results of weight measurements of tiger shrimp in each treatment showed an increase from the beginning and end of the maintenance period. The best increase in shrimp weight was shown by the P1 group with an average initial weight of $0.02 \mathrm{~g}$ and an average final weight of $0.034 \mathrm{~g}$. 
Table 2. Average \pm DS weight $(\mathrm{g})$ of tiger shrimp at the beginning and end of the maintenance period given yeast and lactic acid bacteria probiotic.

\begin{tabular}{|c|c|c|c|}
\hline Treatment & $\begin{array}{l}\text { Initial } \\
\text { weight }\end{array}$ & $\begin{array}{c}\text { Final } \\
\text { weight }\end{array}$ & $\begin{array}{l}\text { Difference in } \\
\quad \text { average } \\
\text { shrimp weight }\end{array}$ \\
\hline P0 & $0.016 \pm 0.0055$ & $0.032 \pm 0.0084$ & 0.016 \\
\hline P1 & $0.020 \pm 0.0173$ & $0.034 \pm 0.0089$ & 0.014 \\
\hline P2 & $0.014 \pm 0.0094$ & $0.016 \pm 0.0055$ & 0.002 \\
\hline P3 & $0.015 \pm 0.0058$ & $0.016 \pm 0.0055$ & 0.001 \\
\hline $\begin{array}{l}\mathrm{P} 0 \\
\text { ye } \\
\text { lac } \\
\text { ba }\end{array}$ & \multicolumn{3}{|c|}{$\begin{array}{l}\mathrm{P} 0=\text { without giving yeast and lactic acid bacteria; } \mathrm{P} 1= \\
\text { yeast and lactic acid bacteria } 25 \mathrm{ml} / \text { week; } \mathrm{P} 2=\text { yeast and } \\
\text { lactic acid bacteria } 50 \mathrm{ml} / \text { week; } \mathrm{P} 3=\text { yeast and lactic acid } \\
\text { bacteria } 75 \mathrm{ml} / \text { week }\end{array}$} \\
\hline
\end{tabular}

Table 3. Average \pm DS length $(\mathrm{mm})$ of tiger shrimp based on treatment at the beginning and end of the maintenance period

\begin{tabular}{|c|c|c|c|}
\hline $\begin{array}{l}\text { Treat- } \\
\text { men }\end{array}$ & Initial length & Final length & $\begin{array}{c}\text { Lenght } \\
\text { differenc } \\
\mathrm{e} \\
\end{array}$ \\
\hline P0 & $12.050 \pm 2.2666$ & $14.734 \pm 0.9489$ & 2.684 \\
\hline P1 & $14.580 \pm 2.6499$ & $17.722 \pm 1.7228$ & 3.142 \\
\hline $\mathrm{P} 2$ & $13.340 \pm 2.1329$ & $14.328 \pm 0.9669$ & 0.988 \\
\hline $\mathrm{P} 3$ & $12.525 \pm 2.1329$ & $14.150 \pm 0.4472$ & 1.625 \\
\hline & $\begin{array}{l}\text { without giving y } \\
\text { and lactic acid b } \\
\text { acid bacteria } 50 \\
\text { ria } 75 \mathrm{ml} / \text { week }\end{array}$ & $\begin{array}{l}\text { t and lactic acid } \\
\text { eria } 25 \mathrm{ml} / \text { week; } \\
\text { week; } \mathrm{P} 3=\text { yeast }\end{array}$ & $\begin{array}{l}\text { acteria; P1 } \\
2=\text { yeast an } \\
\text { d lactic aci }\end{array}$ \\
\hline
\end{tabular}

The results of statistical analysis showed that the provision of yeast and lactic acid bacteria probiotics in groups $\mathrm{P} 0$ and $\mathrm{P} 1$ had a significant effect $(\mathrm{P}<0.05)$ on the increase in the average body length of tiger shrimp. The average length of tiger shrimp in each treatment group increased during the maintenance period. The best increase in the length of tiger Shrimp was shown by the P1 group with an average initial length of $14,580 \mathrm{~mm}$ and an average final length of $17,722 \mathrm{~mm}$.

Observation of the growth of tiger shrimp based on the weights and lengths of shrimps was conducted to determine the rate of growth of shrimps that are kept based on treatment. Based on SNI01-61432006, the weight of tiger shrimp fry is $4.8-20.23 \mathrm{mg}$ and the length of tiger shrimp fry is $10.7-16 \mathrm{~mm}$. Given probiotics with the right dose helps postlarva tiger shrimp feed optimally utilize as needed nutrients in the body [9]. Probiotics in raising tiger shrimp have many benefits, especially for absorbing nutrients from feed [10].

\subsection{Number of lactic acid bacteria and Vibrio sp.on Water Maintenance}

Giving yeast and lactic acid bacteria aims to suppress pathogenic bacteria (Vibrio sp) in water so that the productivity of tiger shrimp is not disturbed. Average \pm $\mathrm{SD}$ of LAB and Vibrio sp in maintenance water based on the treatment group are shown in Table 4.Based on statistical analysis, yeast and lactic acid bacteria administration significantly affected $(\mathrm{P}<0.05)$ the number of lactic acid bacteria and Vibrio sp. Colonies.

Shrimp disease is one of the inhibiting factors in increasing shrimp production. One of them is Vibriosis caused by Vibrio sp, namely Vibrio harveyi. This disease can cause high mortality and is considered as a cause of mass death in shrimp farming [8]. Based on the results achieved, the provision of yeast and lactic acid bacteria probiotics from pineapple and papaya skin waste increases the number of lactic acid bacteria colonies and decreases the number of Vibrio sp colonies in water due to the administration of probiotics in water directly in contact with maintenance water so that it can suppress Vibrio sp.

Tabel 4. Average $\pm \mathrm{DS}$ of LAB and Vibrio sp in maintenance water based on the treatment group $(\log 10 \mathrm{CFU} / \mathrm{ml})$

\begin{tabular}{ccc}
\hline \multirow{2}{*}{$\begin{array}{c}\text { Group } \\
\text { Treatment }\end{array}$} & \multicolumn{2}{c}{ Number of Colonies } \\
\cline { 2 - 3 } & $\begin{array}{c}\text { Lactic acid } \\
\text { bacteria }\end{array}$ & Vibrio sp. \\
\hline P0 & $7.016 \pm 0.009^{\mathrm{a}}$ & $8.009 \pm 0.064^{\mathrm{c}}$ \\
P1 & $8.364 \pm 0.009^{\mathrm{b}}$ & $6.929 \pm 0.004^{\mathrm{b}}$ \\
P2 & $7.114 \pm 0.010^{\mathrm{a}}$ & $6.456 \pm 0.011^{\mathrm{a}}$ \\
P3 & $8.447 \pm 0.047^{\mathrm{b}}$ & $6.505 \pm 0.034^{\mathrm{a}}$
\end{tabular}

Note: $\mathrm{P} 0=$ without giving yeast and lactic acid bacteria; $\mathrm{P} 1=$ yeast and lactic acid bacteria $25 \mathrm{ml} /$ week; $\mathrm{P} 2=$ yeast and lactic acid bacteria $50 \mathrm{ml} /$ week; $\mathrm{P} 3=$ yeast and lactic acid bacteria $75 \mathrm{ml} /$ week

This happens because lactic acid bacteria can produce antimicrobial compounds that can inhibit the growth and activity of pathogenic microorganisms. Antimicrobial compounds produced by lactic acid bacteria include organic acids, hydrogen peroxide and bacteriocin [11]

\subsection{Water Quality for Tiger Shrimp Maintenance}

Observation of water quality during the tiger shrimp rearing period is measured based on temperature, $\mathrm{pH}$, salinity and dissolved oxygen in the water. The results of water quality checks during tiger shrimp maintenance can be seen in Table 5. Based on statistical analysis, the provision of yeast and lactic acid bacteria with different treatment groups had no significant effect $(\mathrm{P}>0.05)$ on maintaining water quality.

Tiger shrimp are eurythermal which can withstand a wide temperature range, which is $22-31^{\circ} \mathrm{C}$. Based on SNI 01-7246-2006, the salinity of water in raising tiger shrimp is $15-42 \mathrm{ppt}$, the oxygen content of water is $>3.5 \mathrm{ppm}$ and the degree of acidity of the water $(\mathrm{pH})$ is between 7.5-8.5 [12]. The range of water quality parameter values for rearing tiger shrimp larvae during maintenance are generally within the normal range or tolerance of tiger shrimp so this factor does not limit the growth and survival of tiger shrimp larvae. 
Table 5. Water quality during tiger shrimp maintenance

\begin{tabular}{lcccc}
\hline \multirow{2}{*}{$\begin{array}{c}\text { Water quality } \\
\text { parameters }\end{array}$} & \multicolumn{4}{c}{ Treatments } \\
\cline { 2 - 5 } & $\mathrm{P} 0$ & $\mathrm{P} 1$ & $\mathrm{P} 2$ & $\mathrm{P} 3$ \\
\hline Temp $\left({ }^{0} \mathrm{C}\right)$ & $28.09 \pm 0.75^{\mathrm{a}}$ & $27.98 \pm 0.66^{\mathrm{a}}$ & $27.94 \pm 0.62^{\mathrm{a}}$ & $27.91 \pm 0.59^{\mathrm{a}}$ \\
Salinity $(\mathrm{ppt})$ & $40.04 \pm 3.24^{\mathrm{a}}$ & $40.33 \pm 3.42^{\mathrm{a}}$ & $40.61 \pm 3.70^{\mathrm{a}}$ & $41.00 \pm 3.88^{\mathrm{a}}$ \\
DO (ppm) & $3.88 \pm 0.50^{\mathrm{a}}$ & $3.77 \pm 0.66^{\mathrm{a}}$ & $3.60 \pm 0.61^{\mathrm{a}}$ & $3.55 \pm 0.66^{\mathrm{a}}$ \\
$\mathrm{pH}$ & $7.79 \pm 0.85^{\mathrm{a}}$ & $7.76 \pm 0.78^{\mathrm{a}}$ & $7.83 \pm 0.81^{\mathrm{a}}$ & $7.81 \pm 0.84^{\mathrm{a}}$ \\
\hline The same superscript in the same line shows no significant effect $(\mathrm{P}>0.05)$
\end{tabular}

\section{Conclusion}

Based on the results of the study it can be concluded that the incubation period of 2 days can increase the number of lactic acid bacteria and fungus in the yeast and lactic acid bacteria probiotics, administration of yeast and lactic acid bacteria at a dose of $25 \mathrm{ml} / 15 \mathrm{~L}$ of water can increase the growth of tiger shrimp and increase the provision of yeast and lactic acid bacteria probiotics up to $75 \mathrm{ml} / 15 \mathrm{~L}$ of water can reduce the amount of Vibrio sp. and does not degrade water quality for tiger shrimp maintenance.

\section{Acknowledgments}

On this occasion, the authors would like to thank the Directorate General of the Ministry of Research and Technology and Education for facilitating the 2019 PKMPE program.

\section{References}

1. Rosenberry B :World shrimp farming. Annual report san diego. Shrimp News International. 1995.

2. Kordi : Penanggulangan Hama dan Penyakit Ikan.; Rineke Cipta. Jakarta. 2004.

3. Balcazar JL, de Blas I, Ruiz-Zarzuela I, et al. : The role of probiotics in aquaculture. Veterinary Microbiology 2006; 114: 173-186

4. Widanarni, Hadiroseyani Y, Sutanti A: Pertumbuhan pascalarva udang windu Penaeus monodon yang diberi Artemia mengandung probiotik Vibrio SKT-b. Jurnal Akuakultur Indonesia, 2013 ; 12(1): 79-85
5. Verschuere L, Rombaut G, Sorgeloos P, Verstraete W: Probiotic bacteria as biological control agents in aquaculture. Microbiology and Molecular Reviews, 2000; 64: 655-671

6. Gatesoupe FJ. :Probiotics and prebiotics for fish culture, at the parting of the ways. Aqua Feeds: Formulation and Beyond, 2005; 2: 3-5

7. Gatesoupe FJ: Updating the importance of lactic acid bacteria in fish farming: natural occurance and probiotic treatments. Journal of Molecular Microbiology and Biotechnology, 2008; 14: 107-114.

8. Feliatra F., Nugroho TT., Silalahi S, et al. : Screening Of Indonesian Original Bacteria Vibrio Sp As A Cause of Shrimp Diseases Based On 16s Ribosomal DNA Technique. Jurnal Ilmu dan Teknologi Kelautan Tropis, 2011; 2(3): 85-99.

9. Praditia FP: Pengaruh Pemberian Bakteri Probiotik Melalui Pakan terhadap Pertumbuhan dan Kelangsungan Hidup Udang Windu Penaeus monodon. Institut Pertanian Bogor, Bogor. 2009.

10. Afrilasari W, Widanarni, Meryandini, A: Effect of Probiotic Bacillus megaterium PTB 1.4 on the Population of Intestinal Microflora, Digestive Enzyme Activity and the Growth of Catfish (Clarias sp.). HAYATI Journal of Biosciences, 2016; 23(4): 168-172.

11. Daten H, Ardyati T: Potensi Penambahan Probiotik (Lactobacillus pentosus K50) untuk Meningkatkan Kualitas Pakan Ikan Air Tawar. Jurnal Biotropika, 2018; 6(2): 64-69

12. Lidaenni A: Pengaruh pemberian bakteri agen biokontrol Vibrio SKT-b dengan dosis yang berbeda terhadap kelangsungan hidup dan pertumbuhan larva udang windu, Panaeus monodon. Institut Pertanian Bogor. Bogor. 2008. 